PUBLIC ADMINISTRATION

\title{
ASSESSMENT AND PROSPECTS FOR THE DEVELOPMENT OF PUBLIC-PRIVATE PARTNERSHIP IN THE REPUBLIC OF KAZAKHSTAN
}

\author{
Jumasheva Sulushash, MBA, Lecturer, Almaty Technological University, Kazakhstan \\ Adilkhanov Madiyar, student, Almaty Technological University, Kazakhstan \\ Yuldashev Dilshat, student, Almaty Technological University, Kazakhstan
}

DOI: https://doi.org/10.31435/rsglobal_conf/25022021/7416

\begin{abstract}
The relevance of the research topic is due to the growing interest in public-private partnership (PPP) in the business cycles of the Republic of Kazakhstan, the largest countries of the world and state institutions. Today it becomes obvious that without an interesting partnership of state and municipal authorities with representatives of private business, it is impossible to achieve the highest stable rates of development of the country.

The article reveals the content of public-private partnership, examines the features of its formation and development in the Republic of Kazakhstan. The conditions for effective public-private partnership have been identified. The article indicates that the ongoing programs to stimulate entrepreneurship through PPP have a positive effect, but a number of problems remain. Based on the results of the PPP assessment in Kazakhstan, directions for improving this type of cooperation have been identified.
\end{abstract}

Keywords: public-private partnership, projects, contracts, economic development, efficiency.

Introduction. The relevance of the research topic is due to the growing interest in publicprivate partnership (PPP) in the business cycles of the Republic of Kazakhstan. Today it becomes obvious that without an interesting partnership of state and municipal authorities with representatives of private business, it is impossible to achieve the highest stable rates of development of the country.

The National Chamber of Entrepreneurs of the Republic of Kazakhstan "Atameken" defines PPP as mutually beneficial cooperation between government bodies and entrepreneurs in industries traditionally related to the state's responsibility on the basis of a balanced distribution of risks, benefits and costs, rights and obligations defined in the relevant agreements [1].

According to A. Kolosov, the essence of PPP should be considered in three aspects:

- in economic terms, PPP acts as a form of relations between institutionally heterogeneous entities (government, business, citizens);

- in the institutional aspect, PPP is a form of realization of state property;

- as a category of management, public-private partnership is a way to combine the mechanisms of competition and coordination [2].

Research results. According to international practice, the development of PPP involves three stages: preparation, implementation and improvement. At the stage of preparation, states study international experience, analyze current legislation, determine the general state policy in the field of PPP and sometimes begin to implement pilot projects.

An analysis of modern foreign practice in organizing PPPs made it possible to identify a number of effective approaches and solutions that ensure the development of public-private partnerships:

- positioning the role of the institution of public-private partnership in the implementation of a wide range of goals determined within the framework of national and regional scientific and technical, structural, investment, social policy;

These goals include: stimulating private sector innovation; expanding funding on a long-term basis for fundamental research and research in the field of creating new technologies; effective use of globalization of innovation; integration of military and civilian production; development of the social sphere;

- a diversified structure of sectors for implementing PPP projects with a clearly expressed priority of types of economic activities related to scientific support of the real sector of the economy, production and social infrastructure;

- creation at the national level of various forms of public-private partnerships, initially focused on the innovative renewal of the economy, ensuring the integration of higher educational institutions, scientific organizations of the public and private sectors, industrial companies; 
- the spread of the practice of public-private partnership from the national and regional levels to the municipal, covering the industries of production and social infrastructure (utilities, education, health care);

- participation of the state in organizing the creation, functioning and development of PPP, along with co-financing, includes its organizational impact on the parameters of the internal and external environment of this institution. Among the first: personnel and their competencies, areas of cooperation between participants, the composition of priority areas for testing new technologies, procedures for their transfer and commercialization. Among the second: the legal framework (adapted or newly created), the tax environment, the contract system;

- the composition of the instruments used by the state in organizing the processes of creating and operating PPPs is diverse and includes, including: foresight, grants, tax incentives, concessional lending, subsidies for multipurpose use, budgetary financing of infrastructure facilities, legislation on the protection of intellectual property [2].

The stage of PPP implementation involves a number of activities, such as: formation of legislation, development of methodological instructions and guidelines, creation of specialized PPP body, expansion of the scope of PPP, etc. The improvement stage is characterized by an increase in activity in the field of PPP and an increase in the level of complexity of projects. This stage assumes further improvement of legislation, as well as models for the implementation of PPP projects.

Conceptual support for the development of public-private partnerships includes substantiation of strategic goals, determination of the directions of this process, substantiation of promising forms and tools of PPP, conditions and algorithms for their effective use.

Recommendations for the development of the PPP mechanism is the need to form a management team that will monitor the progress of its implementation at each stage of the project life cycle and take measures aimed at:

- quality assurance and verification of parameters and conditions for project development;

- reduction of existing and potential administrative and other barriers to the successful implementation of the project.

In this regard, the use of PPP mechanisms requires from the management team a lot of efforts and costs (financial and time), and also makes it more important to apply the principles of project management in the preparation, conclusion and implementation of agreements, and the involvement of consultants at the pre-project stage.

At the stage of launching and developing a PPP project, there are several main stages of project management: 1. Development and approval of the project concept, creation of a working (project) group. 2. technical, legal and marketing analysis of the project implementation conditions. 3. preparation of a feasibility study for the project, including a financial model. 4. Development of an extended matrix of project risks (description of project risk). 5. drawing up a draft agreement or essential and other essential terms of the agreement. 6. conclusion of an investment memorandum on PPP [3].

In the Republic of Kazakhstan, as of June 1, 2020, 786 PPP contracts were concluded in the amount of 1.8 trillion tenge, including 10 at the republican level and 776 at the local level. It attracted 910 billion tenge of investments. As of June 1, 2020, 1/3 of the implemented PPP projects are projects of the third category, that is, they are reimbursed from the current budget expenditures, tariffs and extra-budgetary sources (paid services, etc.). PPP projects of the third category can be considered the most successful PPP projects [4, 5].

One of the examples of the implementation of projects of the third category are projects for the modernization of food blocks and canteens of schools (standard projects covering all schools in a settlement), as well as projects for the construction and operation of dormitories, which are recouped through government orders and student rent payments. Also, in accordance with the Law of the Republic of Kazakhstan "On Public-Private Partnership", the PPP Development Center annually evaluates the implementation of PPP projects, as a result of which the administrators of budget programs (public partners) are provided with recommendations in order to increase the efficiency of planned and ongoing projects.

Based on the results of inspections of PPP contracts carried out by authorized state bodies, a number of problems were identified that were admitted by state bodies in the implementation of PPP projects. At the moment, the administrators of budget programs, together with the Ministry of National Economy of the Republic of Kazakhstan and the PPP Development Center, are working to eliminate the above comments, as well as amend the legislation in the field of PPP. 
Along with this, in Kazakhstan there are examples of project implementation (for example, PPP projects of the third category, recouped from extra-budgetary sources), which are replicated in all regions. There are several times less of them than republican projects, but they require significant financial costs. Some republican projects, concluded within the framework of PPP, have been put into operation, for example, the Nur Zholy automobile checkpoint.

The checkpoint makes it possible to increase the traffic flows of cars, heavy vehicles and passenger buses; information system for managing paperless documents in the field of air cargo transportation (electronic cargo transportation); railway station "Shar-Ust-Kamenogorsk" and others. In 2019, in order to move from quantity to quality of public-private partnership projects, the Ministry of National Economy introduced its own classification.

PPP projects for budget repayment were divided into 3 categories:

1. first category is full redemption. Full repayment of investments and operating expenses of the private partner from the budget;

2. the second category is partial repayment. Return on investment from the budget and services from the market;

3. the third category - no refund from the budget. No compensation for investment and operating expenses from the budget is required. Compensation is made at the expense of services (tariff, government order, paid services, etc.).

Projects implemented under PPP schemes are especially vulnerable during the crisis, due to the complex nature of the PPP institution and high risks (in particular, currency risk). Taking into account the existing statistics, the practice of project implementation and the opinions of stakeholders, the PPP center in the Republic of Kazakhstan presents the following: the concession should be focused only on infrastructure projects related to the obligations of the private party to create and operate the concession facility with the provision of demand risk. Compensation should be made, if necessary, at rates per unit of public service provided (world practice). If the tariff is lower or higher than the required level, a subsidy mechanism or the establishment of a special tariff is applied for concession projects. PPP projects are encouraged to be covered by projects for the purchase of services from a private partner with compensation from the tariff (government order, paid services, etc.).

Thus, the assessment of the established practice of organizing public-private partnerships at the national and regional levels allows us to focus on both its achievements and shortcomings.

The first should include:

- expanding the composition of institutional forms that ensure the integration of public and private investments;

- development of a unified methodological base that determines the structure and content of plans for the development of public-private partnerships;

- using the potential of program-target and strategic management in the development and implementation of plans and programs for the development of public-private partnerships;

- implementation of the achievements of international practice in the field of public-private partnerships based on benchmarking technology.

Among the main shortcomings, one should highlight the low level of variety of forms and instruments of public-private partnership, which significantly limits the possibilities of using its potential.

To form a full-fledged PPP system in the Republic of Kazakhstan, it is necessary to include civil society institutions representing the interests of end users of public goods in its members. When forming a block of three partners in a partnership, the private sector is assigned the function of their direct production at the micro level.

In addition, the country provides for the following measures of state support: 1. government guarantees for infrastructure bonds; 2. attracted government loan guarantees for financing PPP projects; 3. transfer of exclusive rights to state-owned intellectual property objects; 4 . provision of specific donations in accordance with the legislation of the Republic of Kazakhstan; 5. Projects cofinancing; 6. consumer guarantees against the situation of a certain volume of goods (works, services) produced during the implementation of the PPP project.

The development and improvement of PPP procedures continues to this day, and state bodies, as well as with the active participation of representatives of the business community, make and accept proposals for optimizing all processes. As a result, in the fall of last year, significant changes were made: reducing the stages, providing a long-term consumer guarantee, developing document flow standards, registering PPP agreements, launching a single database of a PPP project. 
Conclusions. Thus, the improvement of the legal framework, the formation of organizational structures, an increase in the number of projects - all this indicates the intention to turn PPP into a key element of modernization, structural adjustment and economic growth of the country.

Nevertheless, despite the improved conditions for the implementation of PPP projects and the presence of positive dynamics, today there are a number of issues that require their further solution. In particular, it is necessary to conduct a thorough analysis of sectoral laws in order to remove possible obstacles; consider the possibility of introducing additional tax and budget incentives for the active involvement of business representatives; improve the interaction of the Ministry of National Economy with the National Bank on the issue of collateral. The use of effective solutions in these areas will not keep you waiting for positive results in practice.

The state assumes the functions of planning, organizing, monitoring and regulating at the macro- and meso-levels, which is more in line with its social role. Specific production problems in their entirety are transferred to the private sector, which is more adapted to their solution.

In accordance with the public roles of the two traditional for the Republic of Kazakhstan PPP participants - the state and business structures, they need to apply their inherent tools within the framework of the main management functions: planning, organization, control and regulation. The composition of the instruments is specific for each participant and corresponds to their social roles.

In 2020, few high-quality PPP projects were implemented due to the coronavirus pandemic. More projects are expected in 2021. PPP statistics as of February 2021 according to Kazakhstani Center of PPP is as follows: total PPP projects-1347; project at the stage of competition - 275; implemented contracts-864, total volume of investments $-1130 \mathrm{bln}$. KZ tenge.

\section{REFERENCES}

1. Retrieved from https://atameken.kz/

2. Kolosov A.S. Public-private partnership: content, organization, development management: author. dis. $\mathrm{PhD}$ in Economics. Southwestern State University, Kursk, 2011.

3. Zhangirova R.N. "Development of public - private partnership in the Republic of Kazakhstan", Journal: Bulletin of KazNPU, 2014, Almaty, URL: https://articlekz.com/article/10547.

4. Retrieved from https://primeminister.kz/ru/news/interviews/intervyu-o-razvitie-gchp-v-kazahstane-sostoyanietendencii-i-perspektivy-1053646

5. Retrieved from https://stat.gov.kz/ 